\title{
Second International Conference on Protestant Church Polity: Good Governance in Church and Society today
}

Pretoria, South Africa, 24-27 March 2014

\section{DANIEL BUdA}

The Department for Church History and Church Polity of the Faculty of Theology, University of Pretoria organized a second conference on Church Polity in collaboration with VU University Amsterdam. Aimed mainly but not exclusively at protestant theologians, the conference has dealt with issues related to the responsibilities of churches for good governance in order to properly respond to their mission for their own members as well as for society. The key question has been: to what extent is it possible to speak of "Good governance in church and society today" within the framework of church polity? This question is an invitation to reflect on two main areas of research. The first area concerns internal church life. Ecumenism shows that it is ready, at least in some settings, to concede or change historically grown patterns and definitions. But no confessional tradition can afford to neglect similar challenges. Some Christian traditions, such as the Reformed, seems able to easily integrate modern good governance values, whilst other churches and traditions do not consider it necessary to operate such updates. The second area of concern is external relations of churches, and more particularly; church - state relationships. Should churches be the champions of good governance in society? How do they, and how should they see their responsibilities in this regard? Starting from this problematic, the keynote presenters were invited to reflect upon, from their different perspectives: How can church polity contribute to good governance in church and society in the $21^{\text {st }}$ century?

Eighteen papers were presented during this conference. Most of them were presented by South African participants; however, a good number of presenters came from abroad: Holland, Sweden, Philippines, Zimbabwe and Switzerland. The list of titles presented gives an idea of the diversity of themes presented: Leo Koffeman, Accountability and church discipline: an inconvenient relationship; Christina Landman, Good governance and discipline: Incorporating a mediation process into the Church Order; Anna Tronet, Good governance

Daniel Buda, Rev. PhD Assistant Professor at the Andrei Şaguna Faculty of Orthodox Theology, Lucian Blaga University of Sibiu, Romania; Programme Executive Coordinator for Church and Ecumenical Relations at WCC, Geneva. Contact details: WCC, Route de Ferney 150, 1211 Geneva 2, Switzerland; e-mail: daniel 77bde@yahoo.de. 
in the Church of Sweden: in particular the Principle of Public Access, the Status of Minority-languages and Child Impact Assessment; Peter Aya, Good church governance from Reformed and Presbyterian traditions; Piet Strauss, Church and state relations in South Africa around the declaration of human rights; Pieter Coertzen, Contemporary requirements for good governance in Church and society; Nelus Niemandt, Together towards life and mission - a basis for good governance in Church and Society today; Daniel Buda, Is Renewal Part of a Good Governance of Ecumenical Organizations? Reflections on the Planned Faith and Order World Conference on Renewal - 2017; Albert Jan Stam, Good Governance in Church and World: A Hermeneutical Quest; Godfrey Msiska, The Relation between Democracy and Christianity: Towards an African Discursive "Model"; Helena van Coller, Good governance in the church: treating employees fairly; Johannes Smit, Is the minister of religion an employee of the church? The South African theological discussion; Roy Alexander Surjanegara, Features of Reformed Polity; Wim Dreyer, Church membership and property rights in the light of a church schism; Mary - Anne Plaatjies van Huffel, The 'proprium' of church polity with regard to the international standards of good governance; Joseph Small, POLIS AND ECCLESIA "Good Governance" and the Ecclesia Docens; Johan van Merwe, Church membership: Achilles heel to good governance?; Leslie van Rooi, Speaking out against Government. Historical lessons learned from the former Dutch Reformed Mission Church. 1978 - 1990 and Klippies Kritzinger: Must a URCSA congregation have elders and deacons? An examination of the URCSA Church Order and the Stipulations of the Northern Synod.

A selection of the presentations will be published next year by Litt Verlag in Germany. The participants acknowledged that the different church polities are strongly determined by the characteristics of different Christian traditions with their own particular theologies and ethos, as well as by the nature of the relationships between church and state. During the discussions and after each presentation the need for a stronger connection between theology and church polity was also highlighted. In some churches church polity seems to be determined almost exclusively by the spirit of the world we live in, which is a wrong development. Another dimension of church polity in general today is the ecumenical one. The mutual accountability developed between churches within the ecumenical movement enables churches to learn from each other's experiences also in field of church polity. 